\title{
"Assessment of the social expenditure impact on the economic growth in OECD countries"
}

\begin{tabular}{|c|c|}
\hline AUTHORS & 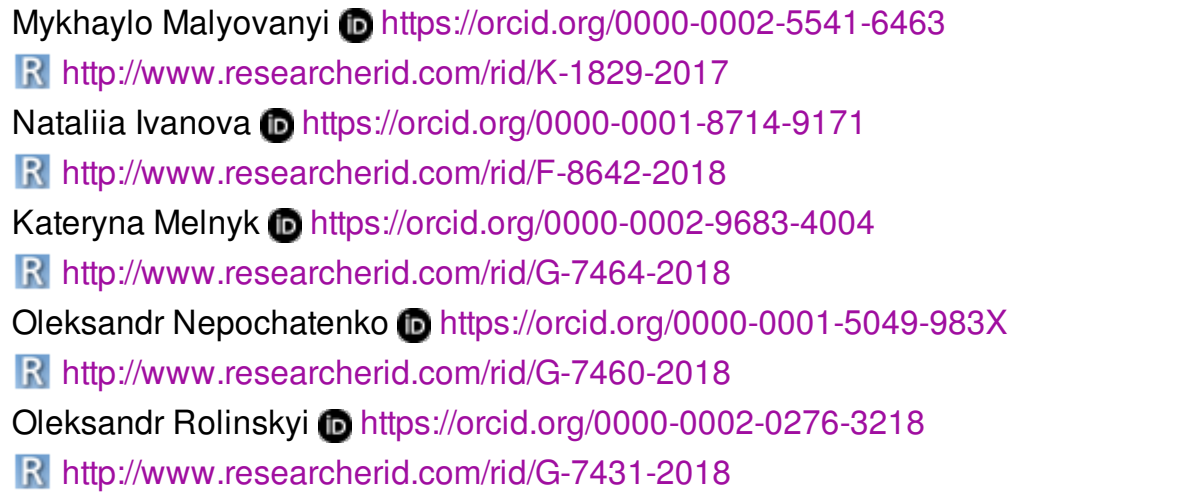 \\
\hline ARTICLE INFO & $\begin{array}{l}\text { Mykhaylo Malyovanyi, Nataliia Ivanova, Kateryna Melnyk, Oleksandr } \\
\text { Nepochatenko and Oleksandr Rolinskyi (2018). Assessment of the social } \\
\text { expenditure impact on the economic growth in OECD countries. Problems and } \\
\text { Perspectives in Management, 16(3), 389-405. doi:10.21511/ppm.16(3).2018.31 }\end{array}$ \\
\hline DOI & http://dx.doi.org/10.21511/ppm.16(3).2018.31 \\
\hline RELEASED ON & Wednesday, 12 September 2018 \\
\hline RECEIVED ON & Friday, 30 March 2018 \\
\hline ACCEPTED ON & Wednesday, 15 August 2018 \\
\hline LICENSE & $\begin{array}{l}(\mathrm{c}) \mathrm{EY} \\
\text { This work is licensed under a Creative Commons Attribution } 4.0 \text { International } \\
\text { License }\end{array}$ \\
\hline JOURNAL & "Problems and Perspectives in Management" \\
\hline ISSN PRINT & $1727-7051$ \\
\hline ISSN ONLINE & $1810-5467$ \\
\hline PUBLISHER & LLC "Consulting Publishing Company "Business Perspectives" \\
\hline FOUNDER & LLC "Consulting Publishing Company "Business Perspectives" \\
\hline
\end{tabular}

NUMBER OF REFERENCES

55

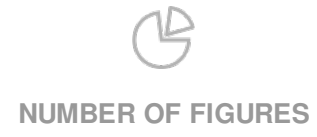

0
NUMBER OF TABLES

9

(C) The author(s) 2022. This publication is an open access article. 


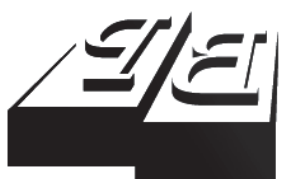

BUSINESS PERSPECTIVES

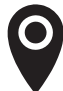

LLC "CPC "Business Perspectives" Hryhorii Skovoroda lane, 10, Sumy, 40022, Ukraine

www.businessperspectives.org

Received on: $30^{\text {th }}$ of March, 2018 Accepted on: $15^{\text {th }}$ of August, 2018

(C) Mykhaylo Malyovanyi, Nataliia Ivanova, Kateryna Melnyk, Oleksandr Nepochatenko, Oleksandr Rolinskyi, 2018

Mykhaylo Malyovanyi, Doctor of Economics, Associate Professor, Vice-Rector of Uman National University of Horticulture, Ministry of Education and Science of Ukraine, Ukraine.

Nataliia Ivanova, Ph.D. in Economics, Associate Professor, Uman National University of Horticulture, Ministry of Education and Science of Ukraine, Ukraine.

Kateryna Melnyk, Ph.D. in Economics, Associate Professor Uman National University of Horticulture, Ministry of Education and Science of Ukraine, Ukraine.

Oleksandr Nepochatenko, Ph.D. in Economics, Associate Professor, Uman National University of Horticulture, Ministry of Education and Science of Ukraine, Ukraine.

Oleksandr Rolinskyi, Ph.D. in Economics, Associate Professor Uman National University of Horticulture, Ministry of Education and Science of Ukraine, Ukraine.

\section{(ㄷ) (i)}

This is an Open Access article, distributed under the terms of the Creative Commons Attribution 4.0 International license, which permits unrestricted re-use, distribution, and reproduction in any medium, provided the original work is properly cited.
Mykhaylo Malyovanyi (Ukraine), Nataliia Ivanova (Ukraine), Kateryna Melnyk (Ukraine), Oleksandr Nepochatenko (Ukraine), Oleksandr Rolinskyi (Ukraine)

\section{ASSESSMENT OF THE SOCIAL EXPENDITURE IMPACT ON THE ECONOMIC GROWTH IN OECD COUNTRIES}

\begin{abstract}
Economic growth is exposed to many socio-economic factors that impact both the formation and allocation of resources. The theoretical part of this article discusses studies by various authors on the social expenditure impact on economic growth, the dependence of this influence on selected funding principles and social policy models. In the empirical part, using the Pooled Mean Group (PMG) procedure and the Fixed Effect Model, the impact of social expenditure on the economic growth in OECD countries is determined. An increased focus is put on assessing the long-term impact of the main types of social expenditures (public and private), based on different financing principles (distribution and accumulation), on the economic growth rates both in OECD in general and in the context of countries (based on the Esping-Andersen's typology) grouped according to social policy models. The following conclusions are drawn: 1) an increase in the share of total social expenditures in the country's GDP negatively af fects economic growth; 2) an increase in the share of private social expenditures in the country's GDP contributes to economic growth; 3 ) the obtained indicators of impact assessment are different depending on a social policy model chosen. The analysis is based on OECD panel data for the period 1980-2013.
\end{abstract}

\section{Keywords}

economic growth, social protection, Pooled Mean Group (PMG) procedure, Fixed Effect Model, social expenditure, social policy, economic growth model

JEL Classification C23, G23, H55

\section{INTRODUCTION}

Social protection of the population is one of the most important areas of any state activity, aimed first of all at stable functioning of society by protecting certain segments of the population from various socio-economic risks (unemployment, illness, poverty, old age, etc.). For that end, the state develops a highly-structured integral system of social protection, the elements of which differ between themselves in terms of operating environment and purpose. This enables to embrace population, which needs support from the state, as much as possible.

The well-developed social protection system makes it possible to effectively deal with poverty, which is one of the main problems of the world community. Therefore, in a postindustrial society based on a developed market economy, social protection plays an important role in ensuring a stable and steady development of the economy. The economic and social components of the state are closely interconnected and affect one another. At the same time, science and practice prove that social expenditures (the total cost of financing all social benefits and programs in the country within the system of social protection of the population financed by public and private funds) should be harmoniously related to the economic indicators of the country, which 
directly affect the formation of the main sources of financing social protection of the population. That is, economic resources should create a fundamental basis and be a form of economic content of social protection.

During the $20^{\text {th }}$ century, in countries throughout the world, there were a constant expansion of the social protection types and forms, increase in the number and extent of social services and assistance, and the formation of corporate responsibility, which allowed to protect the majority of the population from various social risks and threats. The modern "welfare state" concept has gradually developed, which undertakes to provide each citizen with a high level of social protection, to create opportunities for unimpeded and mostly free access to a high quality education and health care system, to reduce inequality in society and poverty as much as possible. At the same time, in recent decades, the growth rate of expenditures for social purposes in most developed countries, including OECD countries, is far ahead of economic indicators. Demographic problem and permanent economic and financial crises have created significant problems in the financial support for the population, which affects not only human wellbeing, but also the economy as a whole. All this forces OECD governments to actively seek ways to reform their social protection systems, accompanied by the emergence of new social policy models, which aim at eliminating contradictions between market laws and social goals. According to Giuliano Bonoli, a Swiss political expert, there is a gradual "dismantlement of the welfare state" (Bonoli, George, \& TaylorGooby, 2000). One of the basic terms for the further stable functioning of the social protection system is the right choice of the future model of financing social expenditures, which, on the one hand, would provide the maximum possible social protection of the population, and, on the other hand, would not create significant negative pressure on the economic development of the state. As a result, there are a number of topical issues: which model of social policy is the most acceptable under current conditions; which principle of financing (solidarity (distributional) or accumulation) should be preferred in reforming the social insurance system; how should public and private social expenditures be correlated and, finally, to what extent do they affect the country's economic development?

\section{LITERATURE REVIEW AND THEORETICAL BASIS}

\subsection{Social costs and economic development relationship}

The financial support for social protection is closely linked to a number of socio-economic factors, the change of which may directly or indirectly affect the sources of its financing. Therefore, as rightly pointed out by Cichon et al. (2004), the development of financial provision must necessarily take place taking into account the potential links between social protection and the economy. This allows not only to build a system of social protection balanced in terms of income and expenditures, but also to ensure the gradual socio-economic development of the entire country.

Social protection of the population is always closely related to the economy and its main determinants (labor market, wages (income), labor pro- ductivity, investment level, economic growth, etc.). At the same time, more and more scientists consider the social protection system not only from a social point of view, but also as a mechanism to stimulate the country's economic development. This requires a deeper analysis of the interconnection between socio-economic factors and social protection of the population, especially in the context of the development and use of financial resources. That said, this connection, as evidenced by the study, is of a mutual nature. That is, not only socio-economic factors affect social protection, but also its tools (various social services and benefits) exert pressure on the dynamics of certain factors. At the same time, this influence can be both positive and negative.

Researching this problem by various scientists (Alderman \& Yemtsov, 2012; Arjona et al., 2003; Barrientos, 2012; Cichon et al., 2004; Feld \& Schneider, 2010; Dafermos \& Papatheodorou, 2010; Furceri \& Zdzienicka, 2011; Piachaud, 2011; Damerau, 2011; Gebregziabher, 2014; Egger et al., 
2016; Murshed \& Mansoob, 2017; Tridico \& Meloni, 2018) made it possible to outline the principal tools, by using which the social protection system can potentially influence factors determining economic growth in the country (Table 1). Table 1 outlines only main tools, through which social protection directly or indirectly influences economic growth. The use of particular instruments has a positive or negative impact on the economic factors that shape the total economic impact. Thus, in particular, increasing the size of taxes or social contributions that are the source of financial resources for social protection will negatively affect the labor market (for example, due to the growth of its shadow component) and the amount of business profits, which ultimately reduces the size of investment resources for the economy and reduces revenues both to the budget system and to various state and non-state social insurance funds. Quite often, private investors are not encouraged to invest in regions where high social security contributions are applicable (Cichon et al., 2004).

At the same time, various instruments of social protection have a positive effect on the economy development: 1) the growth of volume and size of insurance premiums in the accumulation system of social insurance reduces the financial burden on public finances and stimulates the growth of investment in the economy; 2) the growth of social transfers contributes to rising incomes and poverty reduction, which ultimately, through the stimulation of aggregate demand, has a positive impact on the country's economic development; 3 ) reducing inequalities in income, increasing the efficiency of health services, increasing fertility contribute to improving human capital, which is the basis for the steady development of any country's economy; 4) active labor market policies contribute to reducing the number of unemployed persons, creating new jobs, increasing labor mobility and increasing labor productivity, etc.

It should be noted that some socio-economic factors that are catalysts of a positive impact on the country's economic development may often have a negative impact on other socio-economic determinants, which, in some cases, offset their positive effect. Therefore, in many scientific studies, the impact of social protection on economic growth is rather ambiguous. For example, some scholars (Furceri \& Zdzienicka, 2011; Furceri, 2010; Alderman \& Yemtsov, 2012; Alderman \& Hoddinott, 2010; Barrientos \& Scott, 2008; Li, Wang, \& Westlund, 2015) note the positive effect of rising social expenditures (or public expenditure on economic growth from the state budget), while

Table 1. Analysis of the social protection impact on the factors determining economic growth

Source: Based on Damerau (2011), Furceri and Zdzienicka (2011), Arjona et al. (2003), Piachaud (2011), Cichon et al. (2004).

\begin{tabular}{|c|c|c|c|c|}
\hline \multicolumn{2}{|c|}{ Instrument } & \multicolumn{2}{|l|}{ Factor } & $\begin{array}{c}\text { Potential } \\
\text { influence on } \\
\text { the economic } \\
\text { growth } \\
\end{array}$ \\
\hline \multicolumn{5}{|c|}{ Generating financial resources of the social protection system } \\
\hline \multirow{6}{*}{\multicolumn{2}{|c|}{$\begin{array}{l}\text { Taxes (fees) to the budget } \\
\text { and contributions to social } \\
\text { protection (compulsory and } \\
\text { voluntary) } \\
\text { Labor supply } \\
\text { Demand for labor } \\
\text { Savings level } \\
\text { Income inequality } \\
\text { Private investments }\end{array}$}} & Informal economy (shadow economy) & Increases & Positive/negative \\
\hline & & Decreases & Negative & \\
\hline & & Decreases & Negative & \\
\hline & & $\begin{array}{l}\text { Increases (if payments are directed to an accumulation } \\
\text { system)/decreases (if payments are directed to a solidarity } \\
\text { system) }\end{array}$ & Positive/negative & \\
\hline & & Decreases & Positive & \\
\hline & & $\begin{array}{l}\text { Increase (if payments are directed to an accumulation } \\
\text { system)/decrease (if payments are directed to a solidarity } \\
\text { system) }\end{array}$ & Positive/negative & \\
\hline \multicolumn{5}{|c|}{ Using financial resources of the social protection system } \\
\hline \multirow{7}{*}{ Active } & \multirow{7}{*}{$\begin{array}{l}\text { Active programs } \\
\text { in the labor } \\
\text { market }\end{array}$} & Income inequality & Decreases & Positive \\
\hline & & Business profitability & Increases & Positive \\
\hline & & Employment level & Increases & Positive \\
\hline & & Investment in human and physical capital & Increases & Positive \\
\hline & & Infrastructure development (due to public works) & Increases & Positive \\
\hline & & Other public investments & Decrease & Negative \\
\hline & & Social stability & Increases & Positive \\
\hline
\end{tabular}


Table 1 (cont.). Analysis of the social protection impact on the factors determining economic growth

\begin{tabular}{|c|c|c|c|c|}
\hline \multicolumn{2}{|c|}{ Instrument } & \multicolumn{2}{|l|}{ Factor } & \multirow[t]{2}{*}{$\begin{array}{c}\text { Potential } \\
\text { influence on } \\
\text { the economic } \\
\text { growth } \\
\end{array}$} \\
\hline \multicolumn{4}{|c|}{ Using financial resources of the social protection system } & \\
\hline \multirow{5}{*}{\multicolumn{2}{|c|}{ Health protection }} & Social stability & Increases & Positive \\
\hline & & Human capital quality & Increases & Positive \\
\hline & & Income level of public and private health care institutions & Increases & Positive \\
\hline & & Labor productivity & Increases & Positive \\
\hline & & Other public investments & Decrease & Negative \\
\hline \multirow{17}{*}{ Passive } & \multirow{7}{*}{ Unemployment } & Income level of the population & Increases & Positive \\
\hline & & Informal economy (shadow economy) & Increases & Positive/negative \\
\hline & & Labor supply & Decreases & Negative \\
\hline & & Other public investments & Decrease & Negative \\
\hline & & Social stability & Increases & Positive \\
\hline & & Labor market development & Increases & Positive \\
\hline & & $\begin{array}{l}\text { Human capital quality (via financing of retraining or further } \\
\text { training) }\end{array}$ & Increases & Positive \\
\hline & \multirow{4}{*}{$\begin{array}{l}\text { Assistance to } \\
\text { families }\end{array}$} & Human capital quality & Increases & Positive \\
\hline & & Income level of the population & Increases & Positive \\
\hline & & Social stability & Increases & Positive \\
\hline & & Other public investments & Decrease & Positive \\
\hline & \multirow{6}{*}{ Other assistance } & Income level of the population & Increases & Positive \\
\hline & & Social stability & Increases & Positive \\
\hline & & Labor supply & Decreases & Negative \\
\hline & & Labor productivity & Increases & Positive \\
\hline & & Informal economy (shadow economy) & Increases & Positive/negative \\
\hline & & Other public investments & Decrease & Negative \\
\hline
\end{tabular}

other quite carefully interpret the results of their own research. Arjona et al. (2003), pointing out that countries with high economic development have a well-developed system of social protection of the population with a significant financial resources, observe that it is still not proven whether such an increase in social expenditures leads to faster economic growth. Other authors (Hansson \& Henrekson, 1994; Commander, Davoodi, \& Lee, 1997; Gwartney, Lawson, \& Holcombe, 1998; Levy, 2007; Sahn \& Alderman, 1996) argue that rising costs for social protection in general have a negative impact on the economic growth. According to the current article authors, such discrepancies in the results are due to the specific features of social policy models and selected funding principles.

\subsection{Social policy models and their financing peculiarities}

There are many different science-based approaches to systematizing social policy models. The most extensive research in this area was conducted by Gøsta Esping-Andersen (1990), a Danish soci- ologist. Summarizing significant historical and empirical material, he identified three types or, as he called them, three "modes of welfare capitalism" - neoliberal (or American), social-democratic (Scandinavian, Swedish model of social policy) and conservative-corporate (Franco-German). In his study "The Three Worlds of Welfare Capitalism" (1990), Esping-Andersen characterizes the above types of a welfare state, which in fact represent the main models of a modern social policy existing in economically developed Western countries. All the studies analyzed (Aiginger, 2008; Püss, Viies, \& Maldre, 2010; Bonoli, 2000; Ferrera, 1996; Kerem \& Põder, 2009; Aspalter, 2006; Ebbinghaus, 2012; Adascalitei, 2012; Diamond \& Lodge, 2013; Miyamoto, 2003; Palier, 2006; Sinanoglu, 2013; Kostadinova, 2014), which involve the systematization of social policy models or typologies of countries based on social policy models, are largely based on the study by Esping-Andersen (1990).

Summarizing the existing scientific approaches to systematization of social policy models, the 
Table 2. Social policy models

Source: Proposed by the authors.

\begin{tabular}{|c|c|c|c|c|c|}
\hline $\begin{array}{l}\text { Anglo-Saxon } \\
\text { model (liberal, } \\
\text { neoliberal, } \\
\text { transatlantic) }\end{array}$ & $\begin{array}{c}\text { Continental } \\
\text { European model } \\
\text { (Bismarck, } \\
\text { conservative- } \\
\text { corporate) } \\
\end{array}$ & $\begin{array}{c}\text { Scandinavian } \\
\text { model (northern, } \\
\text { Swedish, social } \\
\text { democratic) }\end{array}$ & $\begin{array}{l}\text { Mediterranean } \\
\text { model (southern) }\end{array}$ & $\begin{array}{c}\text { Central } \\
\text { and Eastern } \\
\text { European } \\
\text { model }^{1}\end{array}$ & $\begin{array}{c}\text { Liberal } \\
\text { conservative } \\
\text { model }\end{array}$ \\
\hline $\begin{array}{l}\text { USA, UK, Ireland, } \\
\text { Canada, New } \\
\text { Zealand, Australia, } \\
\text { Mexico }\end{array}$ & $\begin{array}{l}\text { Germany, Austria, } \\
\text { France, Belgium, } \\
\text { Luxembourg }\end{array}$ & $\begin{array}{l}\text { Sweden, Norway, } \\
\text { Finland, Denmark, } \\
\text { Iceland, the } \\
\text { Netherlands }^{2}\end{array}$ & $\begin{array}{l}\text { Italy, Spain, Greece, } \\
\text { Portugal, Israel }\end{array}$ & $\begin{array}{l}\text { Czech Republic, } \\
\text { Estonia, Hungary, } \\
\text { Latvia, Poland, } \\
\text { Slovakia, Slovenia }\end{array}$ & $\begin{array}{l}\text { Japan, Korea, } \\
\text { Switzerland }\end{array}$ \\
\hline
\end{tabular}

authors of the current article have distributed 33 OECD countries by six types of social models (Table 2).

Despite the variety of social policy models common in OECD countries, the financial support for their social security systems can always be defined as a system of monetary relations of a distributive nature, in which, through taxes and special contributions, centralized and decentralized funds of future financial resources are formed for social benefits financing. The relations arising in the system of social protection with regard to the formation and use of financial resources are undoubtedly of a distributive nature. Therefore, under expanded reproduction, support for unemployable members of society, as well as those who need material or other assistance, is possible only at the expense of part of the added value or gross domestic product, which is distributed in their favor. Moreover, despite various conditions for the social protection systems functioning in the OECD countries, all of them are based on two basic principles of the financial resources development and use - distributive and accumulative ones.

Distributive financing implies that financing of current liabilities is executed by means of tax financing or contribution financing to centralized or decentralized social protection funds. The majority of state social welfare funds that finance public social expenditures (pension insurance, temporary disability insurance, industrial accident insurance, unemployment insurance, health care, etc.) operate on a distribution basis.
Accumulative financing involves accumulation of funds received by means of investing in various financial assets. At the expense of these funds, under certain conditions specified by either a contract or a legislative act, private social expenditures are financed for the persons who benefited from contributions.

Within these principles of funding, two main schemes of social protection organization are emphasized: tax-financed and contributory, that is, financing at the expense of insurance premiums. Usually, countries combine these schemes, but the relationship between them depends on the social policy model. For example, in the countries of the continental European model, the insurance principle prevails, when the main source of financing is the system of compulsory state social insurance, the funds of which are formed at the expense of insurance premiums. At the same time, in recent years, tax-based financing becomes increasingly important in this model (Manow, 2010). In the Nordic countries, social protection systems were funded mainly by taxes, although there is a gradual increase in the share of financing of social payments at the expense of insurance premiums. Nevertheless, to date in Denmark and Norway, the share of public funds in the social benefits financing is more than 60\% (Morel \& Palme, 2013). In the United States and the UK, a significant proportion of social spending is provided by non-state social insurance institutions (non-state pension funds and insurance companies) that use the accumulative principle of funding.

1 It should be noted that the countries included in this group are at the stage of shaping their social protection systems, and therefore can change the type of social model in the near future. For example, the social system of Estonia, by its characteristics, already tends towards the Anglo-Saxon (liberal) model of social policy.

2 The Netherlands has previously been referred to the continental European social model, but now the country has some features (e.g., labor market characteristics) that resemble more closely the Scandinavian countries. 
In the current context of the world economy development and socio-demographic changes, the question arises: How to combine these principles and schemes of financing to preserve the existing level of social protection of the population on the one hand, and not to harm the country's economic development, on the other?

In order to describe the overall financial equilibrium of the social protection system, Cichon et al. (2004, p. 221) developed an equation that can be applied to: systems of compulsory state social insurance; to systems that are fully financed by taxes; and to all types of interim financing:

$$
R_{0}+\sum_{t=0}^{\infty} \pi_{t} \cdot T I W_{t} \cdot r_{t}=\sum_{t=0}^{\infty} T E X_{t} \cdot r_{t}
$$

where $t=0, \ldots 4$ - years; $R_{0}$ - initial reserve; $\pi_{t}$ premium rate in year $t ; r_{t}$ - discount interest rate in year $t ; T I W_{t}$ - total amount of wages and income from which insurance contributions are paid in year $t ; T E X_{t}$ - total expenditures in year $t$.

The observance of this equilibrium in the medium and long term is violated by a number of factors that can negatively affect both via the reduction of money formation sources and through the costs increase: economic (economic growth, employment rate, wages, inflation rate, interest rate); demographic (population structure, active population, mortality and fertility rate, life expectancy); administrative or political (the structure of the social protection system, the size of the basic social benefits, the number and structure of the social assistance recipients), etc.

It should be also noted that the influence of any factor depends on the existing social model. Therefore, in order to minimize the impact of various risks (demographic, economic, social, and political) most countries now reform their social protection systems and seek a balance between the two principles of financial provision for social protection. This is especially true due to the demographic problems existing in most OECD countries. For example, if in 1950 the United States had 7.98 persons of working age (16-64) per person of the unemployable age (65+), then in 2013, this number was 4.71 persons. In all OECD countries, this ratio deteriorated twice in the period 19502013, and even more in some countries (Finland - from 9.59 to 3.38, Greece - from 9.56 to 3.23, Israel from 17.88 to 5.79 , etc.) (OECD Stat, 2018).

Complex demographic processes in the OECD countries are accompanied by a steady increase in the share of social spending in GDP (for example, in Italy, this share increased from $10.3 \%$ in 1980 to $30.0 \%$ in 2013 , and in the UK, from $19.0 \%$ to 27.8\%) (OECD Stat, 2018), which requires more and more additional financial resources each year to meet social needs, subject to a reduction in the main sources of funding.

Influenced by economic and demographic changes, countries gradually reformed their social protection systems and chose two approaches: 1 ) increasing the efficient functioning of the existing social protection system without more extensive use of the accumulative financing (private sector) (Austria, Belgium, France, Finland, Greece, Italy). In these countries, the share of public expenditures in total social costs has not only decreased, but has also increased; 2) expansion of the (private) accumulative financing principle, accompanied by a reduction in the share of public expenditure in total social expenditures (Canada, Chile, Iceland, Israel, the Netherlands, Sweden, Switzerland, United Kingdom, USA).

Under current conditions of economic, social and demographic development of the OECD countries, the increase in the share of private social expenditures financed by financial sources, which is formed based on the accumulative principle of financing, has a positive effect on the country's economic development. This is evidenced by the results of the analytical grouping, which made it possible to identify the relationship between the share of private social expenditures in total costs and the GDP per capita in OECD countries for the period from 1980 to 2013 (Table 3).

The analytical grouping results indicate that there is a correlation between the share of private social expenditures in the total expenditures and GDP per capita. The obtained empirical correlation between these factors was $\eta=0.413$. This indicates that the connection between $Y$ and the factor of $X$ is moderate. To confirm the connection received, the statistical significance of the linkage strength 
Table 3. Results of the OECD countries analytical grouping according to the correlation between the share of private social expenditures in the total costs and GDP per capita (average for the years from 1980 to 2013)

Source: Authors' calculation based on the OECD data. Retrieved from http://stats.oecd.org/ (application date - March 14, 2018).

\begin{tabular}{|c|c|c|c|}
\hline $\begin{array}{l}\text { Groups, share of private } \\
\text { social expenditures in total } \\
\text { costs, } \%\end{array}$ & $\begin{array}{c}\text { Number } \\
\text { of observations }\end{array}$ & $\begin{array}{l}\text { Average value of private } \\
\text { social expenditures in total } \\
\text { costs, } \%\end{array}$ & $\begin{array}{c}\text { Average GDP per capita, } \\
\text { at fixed } 2010 \text { prices, } \\
\text { USD on a PPP basis }\end{array}$ \\
\hline $0.02-4.36$ & 84 & 1.92 & $24,612.68$ \\
\hline $4.36-8.7$ & 77 & 6.7 & $33,345.24$ \\
\hline $8.7-13.04$ & 48 & 10.36 & $33,126.67$ \\
\hline $13.04-17.38$ & 21 & 14.7 & $35,716.52$ \\
\hline $17.38-21.72$ & 25 & 19.79 & $31,332.7$ \\
\hline $21.72-26.06$ & 22 & 24.24 & $35,447.08$ \\
\hline 26.06-30.4 & 10 & 27.03 & $42,735.58$ \\
\hline $30.4-34.74$ & 5 & 32.88 & $29,854.11$ \\
\hline $34.74-39.08$ & 8 & 37.33 & $41,625.76$ \\
\hline Total & 300 & - & - \\
\hline
\end{tabular}

indicator was checked. In order to check the null hypothesis that general correlation coefficient (empirical correlation relation) of a normal twodimensional random variable equals 0 , with the competing hypothesis $H 1 \neq 0$ at the $\alpha$ significance level, one must calculate the observed value of the criterion $t_{\text {actual }}=\eta n-21-\eta 2$ and according to the table of the Student distribution critical points, to determine the critical point of $t_{\text {critical }}$ of the bilateral critical area by the given level of significance $\alpha$ and the number of freedom degrees $k=n-2$. If $t_{\text {actual }}<t_{\text {critical }}$, there is no reason to reject the null hypothesis.

If $t_{\text {actual }}>t_{\text {critical }}$, the null hypothesis is rejected.

In our case $t_{\text {actual }}=7.83$.

According to Student's table with a significance level $\alpha=0.05$ and degrees of freedom $k=298$, one can find $t_{\text {critical }}$ :

$$
t_{\text {critical }}\left(n-m-1 ; \frac{\alpha}{2}\right)=(298 ; 0.025)=0 \text {, }
$$

where $m=1$ is the number of explanatory variables.

Since $t_{\text {actual }}>t_{\text {critical }}$, the hypothesis that the correlation coefficient equals 0 is rejected. In other words, the correlation coefficient is statistically significant. At the same time, the determination coefficient in this case is only $\eta 2=0.1706$. That is, the $17.06 \%$ variation in the effective indicator (regression coefficient) is due to the differences between the characteristics, and $82.94 \%$ is due to other factors.

However, this analytical grouping does not provide an opportunity to substantiate the positive effect of the increase in private social expenditures (based on the accumulative principle of financing) on economic growth, taking into account other factors (as evidenced by the resulting coefficient of determination) and the peculiarities of social models used in OECD countries. Therefore, in order to objectively and reasonably assess the impact of social expenditures (both public and private) on the economic growth and to define promising directions for the social protection systems development in the OECD countries, there is a need for a deeper and formalized analysis of this scientific challenge.

\section{RESEARCH AIM}

The purpose of this study is to assess the impact of social expenditure on the economic growth both in general and in terms of its types (public and private) in OECD countries, taking into account the social policy model features. 


\section{METHODS}

\subsection{Description of the economic growth model}

The calculations made in this research are based on the neoclassical model of economic growth, developed by Robert Solow (1956), an American economist, and independently, by the Australian economist Trevor Swan (1956). It was built on the basis of an aggregative two-factor Cobb-Douglas production function. The model uses indicators that change significantly only in the long run as the labor productivity (RL) dependence on the capital employment ratio (E) (Grodsky, 2015).

In the context of scientific and technological progress in the economy, the Solow model could not simply be based on new data on the elasticity indicator in the production function and, therefore, since the 1980's, attempts have been made to develop a theory of growth towards creating endogenous models that contain internal impulses of increased returns of production factors. Paul M. Romer (1986), an American economist, began to consider three-factor production function, instead of two-factor one, with labor power, capital goods and "knowledge". Another American, Robert E. Lucas (1988), proposed to consider the "human capital" factor as the result of learning in the production process. Mankiw, Romer, and Weil (1992) have developed a growth model (MRW model), containing the "human capital" factor, which made it possible to formally consider it as an economic development model.

The empirical approach used in this study begins with the calculation of the basic model of economic growth, and then an extended model analysis is carried out, as suggested by Arjona et al. (2002), to determine the impact of active and passive social expenditures on the economic growth. The base model, according to the MRW model, also includes the convergence factor (Bassanini et al., 2001), besides the main determinants (physical capital, population growth and human capital):

$$
\begin{aligned}
& \Delta \ln _{i, t}=a_{0, i}-\varphi \ln y_{i, t-1}+a_{1, t} \ln s_{i, t}^{K}+ \\
& +a_{2, i} \ln h_{i, t}-a_{3, i} n_{i, t}+\sum_{j=4}^{m} a_{j, i}+a_{m+1, i} t+ \\
& +b_{1, i} \Delta \ln s_{i, t}^{K}+b_{2, i} \Delta \ln h_{i t}+b_{3, i} \Delta n_{i, t}+ \\
& +\sum_{j=4}^{m} b_{j, i} \Delta \ln V_{i, t}^{j}+\varepsilon_{i, t}
\end{aligned}
$$

where $S^{K}$ - propensity to accumulate physical capital; $h$ - human capital; $n$ - population growth; $V^{j}$ - vector of variables influencing economic efficiency; $t$ - time trend; $b$-regressors fix the short-time dynamics, and $\varepsilon$ denotes the standard error (Bassanini et al., 2001).

Additionally, a basic and expanded model of economic growth for groups of countries is calculated based on their social model (OECD countries are grouped according to social models in Table 2).

\subsection{Data}

Economic and statistical surveys were conducted in 33 OECD countries (except for Chile and Turkey) for the period 1980-2013 (902 observations $)^{3}$. This period was chosen taking into account two factors: 1) the availability and completeness of all data necessary for econometric calculations (the main factors were chosen based on the economic growth model proposed by Bassanini et al. (2001); 2) this period is characterized by a gradual shift away from the concept of the "welfare state" and the gradual growth of the accumulative financing in the social protection systems of the OECD countries.

The extent of social expenditures per capita is taken from the OECD Social Expenditure Database (SOCX). The other indicators included in the econometric model were based on: 1) OECD Analytical Database for: a) gross domestic product (GDP): GDP per capita at constant prices in 2010, USD per purchasing power parity (PPP); b) gross fixed capital formation (GFCF) per capita at constant 2010 prices, USD per PPP; 3) the

3 Data from individual OECD countries, due to their lack in the OECD Analytical Database (mostly Central European and other parts of the world that joined the OECD after 1980), are taken for other periods than the basic one: from 1980 to 2013 (Czech Republic - 19952013, Estonia - 2004-2013, Greece - 1983-2013, Hungary - 1999-2013, Iceland - 1990-2013, Israel - 1995-2013, Korea - 1990-2013, Latvia - 1997-2013, Mexico - 1990-2013, Poland - 2002-2013, Slovak Republic - 1995-2013, Slovenia - 1996-2013). 
number of working age people (15-64), persons; 2) World Bank Open Data for the average number of schooling years for persons aged 25+, years.

\subsection{Variables used in empirical studies}

Basic variables used in the empirical analysis:

- dependent variable $(\Delta \log Y)$. Real GDP per capita at constant 2010 prices, USD per PPP;

- $\quad$ convergence $(\Delta \log Y-1)$;

- physical capital accumulation $(\Delta \log S K)$. Gross fixed capital formation (GFCF) per capita at constant 2010 prices, USD per PPP;

- human capital $(\Delta \log H)$. The average number of schooling years for persons aged $25+$, years;

- population growth $(\Delta \log P)$. Number of able-bodied population (aged 15 to 64), persons.

Additional variables included in the empirical analysis to assess the social expenditure impact on the economic growth:

- total social expenditure $(\Delta \log N S E)$. Total amount of public and private social expenditures per capita at constant prices in 2010, USD per PPP;

- public social expenditures $(\Delta \log P S E)$. Total amount of state social expenditures per capita at constant prices in 2010, USD per PPP;

- private social expenditures $(\Delta \log \operatorname{Pr} S E)$. Total amount of state social expenditures per capita at constant prices in 2010, USD per PPP.

\subsection{Substantiating the econometric research technique}

In this study, panel data are used for econometric calculations. Thanks to the special structure, the panel data allow to build more flexible and meaningful models and getting answers to questions that are not only accessible within, for example, spatial data-based models. There is an opportunity to take into account and analyze the individual differences between economic units, which cannot be made as part of standard regression models. Often, unobservable factors are correlated with other variables. As part of regression models, this means that the unobservable factor is a significant variable in the model and its exclusion leads to shifting estimates of other parameters. In other words, panel data models allow for more accurate parameter estimation (Grodsky, 2015).

To calculate panel data, the following economic and statistical methods are usually used:

\section{Pooled OLS Regression;}

- Fixed Effect or LSDV Model; and

- Random Effect Model (Random Effect Regression).

When working with panel data, there is always a problem which model (pooled regression, fixed or random effect model) should be selected. At the content level, the difference between models can be interpreted as follows. The pooled model assumes that economic units do not have individual differences, and in some simple situations such an assumption is justified. In a fixed effect model, it is assumed that each economic unit is unique and cannot be considered as the result of random selection from a certain general population. This approach is fair when it comes to countries, large regions, industries, and large enterprises. If the objects fell into the panel as a result of a sample from a large population, then a model with a random effect is acceptable. Small firms, households, and individuals may provide an example. It should, however, be emphasized that in similar situations (especially for a small number of economic units), there may be a question of the existence of individual differences (Baltagi, 2005).

There are statistical criteria that can partially solve the problem of choosing a model using standard hypothesis testing techniques. To select the model that is most adequate for the analyzed data, a pair comparison of the estimated models has been carried out. 
1. Regression with random effect versus regression with fixed effect (Hausman test). In a Random Effect Model, it is assumed that individual effects and explanatory variables do not correlate. The hypothesis is checked in the test:

$H_{0}: \quad \operatorname{corr}\left(u_{i}, x_{i t}\right)=0, i=1, \ldots, N, t=1, \ldots, T$

versus an alternative:

$H_{0}: \quad \operatorname{corr}\left(u_{i}, x_{i t}\right) \neq 0, i=1, \ldots, N, t=1, \ldots, T$.

2. Pooled Regression Model versus Fixed Effect Model (Wald test). Testing can be done using the well-known $F$-criterion. Wald criterion examines the hypothesis that all individual effects equal zero.
The following results were obtained using the EViews 9 program (Tables 4-6).

Note: R-squared - 0.017772; F-statistic - 2.699032; Prob - 0.013304; Durbin-Watson stat - 1.171557.

The determination coefficient in the pooled regression model is negligible (R-squared - 0.018676 ) to assume that the chosen model properly describes the relationship between economic growth and selected factors. In addition, the pooled regression model received negative coefficients at the human capital logarithm, which does not correspond to the socio-economic nature of the indicator.

The Hausman and Wald tests yielded following results:

Table 4. Pooled Regression for the logarithm of real GDP per capita and the logarithm of socioeconomic factors

Source: Authors' calculation based on the OECD data. Retrieved from http://stats.oecd.org/ (application date - March 14, 2018).

\begin{tabular}{|c|c|c|c|c|}
\hline Real GDP per capita $(\Delta \log Y)$ & Coefficient & Std. error & t-statistic & Prob \\
\hline Logarithm of a constant & 119.9726 & 12.54026 & 9.566998 & 0.0000 \\
\hline Lagged real GDP $(\Delta \log Y-1)$ & $-2.13 \mathrm{E}-06$ & $1.20 \mathrm{E}-06$ & -1.770634 & 0.0770 \\
\hline Physical capital accumulation $(\Delta \log S K)$ & 0.071228 & 0.022148 & 3.215984 & 0.0013 \\
\hline Stock of human capital $(\Delta \log H)$ & -0.095156 & 0.056671 & -1.679088 & 0.0935 \\
\hline Population growth $(\Delta \log P)$ & -0.154195 & 0.122376 & -1.260018 & 0.2080 \\
\hline Public social expenditure $(\triangle \log P S E)$ & -0.029092 & 0.22983 & -1.265823 & 0.0359 \\
\hline Private social expenditure $(\Delta \log \operatorname{Pr} S E)$ & 0.000447 & 0.000556 & 0.804152 & 0.0215 \\
\hline
\end{tabular}

Note: R-squared - 0.018676; F-statistic - 2.838916; Prob - 0.009616; Schwarz criterion - 4,930725; Hannan-Quinn crit. 4.907680; Durbin-Watson stat - 1.150661 .

Table 5. Fixed Effect Regression for the logarithm of real GDP per capita and the logarithm of socioeconomic factors

Source: Authors' calculation based on the OECD data. Retrieved from http://stats.oecd.org/ (application date - March 14, 2018).

\begin{tabular}{|c|c|c|c|c|}
\hline Real GDP per capita $(\Delta \log Y)$ & Coefficient & Std. error & t-statistic & Prob \\
\hline Logarithm of a constant & 133.6819 & 19.44201 & 6.875930 & 0.0000 \\
\hline Lagged real GDP $(\Delta \log Y-1)$ & $-2.30 \mathrm{E}-06$ & 1.17E-06 & -1.962031 & 0.0501 \\
\hline Physical capital accumulation $(\Delta \log S K)$ & 0.093633 & 0.0345 & 2.555160 & 0.0108 \\
\hline Stock of human capital $(\Delta \log H)$ & -0.646255 & 0.135190 & -4.780341 & 0.0000 \\
\hline Population growth $(\Delta \log P)$ & -0.180338 & 0.188102 & -0.958726 & 0.3380 \\
\hline Public social expenditure $(\triangle \log P S E)$ & -0.087118 & 0.023195 & -3.755973 & 0.0002 \\
\hline Private social expenditure $(\Delta \log \operatorname{Pr} S E)$ & 0.000251 & 0.000545 & 0.460641 & 0.0152 \\
\hline
\end{tabular}

Note: R-squared - 0.140895; F-statistic - 3.724574; Prob - 0.000000; Schwarz criterion - 5.039119; Hannan-Quinn crit. 4.910730; Durbin-Watson stat -1.312158 . 
Table 6. Random Effect Regression with for the logarithm of the real GDP per capita and the logarithm of socio-economic factors

Source: Authors' calculation based on the OECD data. Retrieved from http://stats.oecd.org/ (application date - March 14, 2018).

\begin{tabular}{|c|c|c|c|c|}
\hline Real GDP per capita $(\Delta \log Y)$ & Coefficient & Std. error & t-statistic & Prob \\
\hline Logarithm of a constant & 121.6180 & 12.77672 & 9.51878 & 0.0000 \\
\hline Lagged real GDP $(\Delta \log Y-1)$ & -2.20 E06 & 1.15E-06 & -1.911957 & 0.0562 \\
\hline Physical capital accumulation $(\Delta \log S K)$ & 0.068558 & 0.022575 & 3.036878 & 0.0025 \\
\hline Stock of human capital $(\Delta \log H)$ & -0.135621 & 0.061141 & -2.218175 & 0.0268 \\
\hline Population growth $(\Delta \log P)$ & -0.155613 & 0.124527 & -1.249634 & 0.2118 \\
\hline Public social expenditure $(\triangle \log P S E)$ & -0.039028 & 0.22142 & -1.762609 & 0.0783 \\
\hline Private social expenditure $(\Delta \log \operatorname{Pr} S E)$ & 0.000429 & 0.000532 & 0.805668 & 0.0206 \\
\hline
\end{tabular}

1. Hausman test (Random Effect Model or Fixed Effect Model). In this case, the null hypothesis assumes no coefficient difference, the value of the criterion $\chi 2=75.729404$, the significance level $p=0.0000$. Since the $p$-level is less than 0.01 , the main hypothesis is rejected. Thus, the Fixed Effect Model better describes the data than the Random Effect Model.

2. Wald test (Pooled OLS Regression Model or Fixed Effect Model). The test results showed that the value of the criterion is $F=3.457828$, the significance level $p=0.0000$. Since the $p$ level is less than 0.01 , the main hypothesis is rejected. Thus, the Fixed Effect Model better describes the data than the Random Effect Model.

Thus, it is the Fixed Effect Model that takes into account the panel data structure to obtain a meaningful and substantiated modeling that can be used to estimate economic growth, depending on the selected socio-economic indicators.

Bassanini et al. (2001) recommend using the Pooled Mean Group (PMG) procedure for calculations, in addition to the above calculation methods. According to Bassanini et al. (2001), this method allows to minimize the disadvantages of the above-mentioned methods and taking into account the impact of socio-economic factors in the long run, considering the particularities of the countries included in the analysis.

It should be noted that none of the economic-statistical methods makes it possible to eliminate all problems arising in the panel data analysis. Therefore, in order to obtain more reliable results, two methods of panel data analysis are used in this research: The Fixed Effect Model and the Pooled Mean Group (PMG) procedure.

\section{RESULTS}

Table 7 presents the calculation results of the of social expenditure impact on the economic growth using the Pooled Mean Group (PMG) procedure. Impact assessment is carried out by gradual expansion of the model through the inclusion of new factors (net total social expenditure, public social expenditure, and private social expenditure). At the same time, calculations were carried out both for the entire population of the country and only for the able-bodied population (aged 15 to 64).

In general, the model effectively characterizes the socio-economic factors influence on the economic growth, the main factors are significant and the received characteristics correspond to their socio-economic content. It should be also noted that positive coefficients have been obtained in the model that characterize the effect of the growth rate of the able-bodied population on the pace of economic growth per capita, which is not expected. As Arjona et al. (2002) note, "higher population growth negatively affects the GDP per capita increase". However, these coefficients were statistically insignificant, and, therefore, the impact of this indicator on the economic growth is rather ambiguous. 
Table 7. Assessment of the social expenditure impact (public and private) on the economic growth

Source: Authors' calculation based on the OECD data. Retrieved from http://stats.oecd.org/ (application date - March 14, 2018).

\begin{tabular}{|c|c|c|c|c|c|c|}
\hline \multirow{4}{*}{ Estimated coefficients } & \multicolumn{6}{|c|}{ Pooled Mean Group (PMG) procedure } \\
\hline & \multicolumn{4}{|c|}{ Total population } & \multicolumn{2}{|c|}{$\begin{array}{l}\text { Able-bodied } \\
\text { population }\end{array}$} \\
\hline & 1 & 2 & 3 & 4 & 5 & 6 \\
\hline & Baselin & Net total & Public & Private & Public & Private \\
\hline Lagged real GDP $(\Delta \log Y-1)$ & $\begin{array}{l}-0.012 \\
(0.005)^{* *}\end{array}$ & $\begin{array}{l}-0.015 \\
(0.007)^{* *}\end{array}$ & $\begin{array}{l}-0.015 \\
(0.008) * *\end{array}$ & $\begin{array}{l}-0.012 \\
(0.005)^{* *}\end{array}$ & $\begin{array}{l}-0.016 \\
(0.007)^{* *}\end{array}$ & $\begin{array}{l}-0.012 \\
(0.005)^{* *}\end{array}$ \\
\hline Physical capital accumulation $(\Delta \log S K)$ & $\begin{array}{c}0.033 \\
(0.011)^{* * *}\end{array}$ & $\begin{array}{c}0.038 \\
(0.009)^{* * *}\end{array}$ & $\begin{array}{c}0.034 \\
(0.010)^{* * *}\end{array}$ & $\begin{array}{c}0.036 \\
(0.011)^{* * *}\end{array}$ & $\begin{array}{c}0.036 \\
(0.011)^{* * *}\end{array}$ & $\begin{array}{c}0.035 \\
(0.011)^{* * *}\end{array}$ \\
\hline Stock of human capital $(\Delta \log H)$ & $\begin{array}{c}0.019 \\
(0.019) *\end{array}$ & $\begin{array}{c}0.027 \\
(0.019) *\end{array}$ & $\begin{array}{c}0.019 \\
(0.019)^{*}\end{array}$ & $\begin{array}{c}0.023 \\
(0.019)^{*}\end{array}$ & $\begin{array}{c}0.021 \\
(0.019)^{*}\end{array}$ & $\begin{array}{c}0.023 \\
(0.019)^{*}\end{array}$ \\
\hline Population growth $(\Delta \log P)$ & $\begin{array}{l}0.236 \\
(0.259)\end{array}$ & $\begin{array}{l}0.366 \\
(0.249)\end{array}$ & $\begin{array}{l}0.411 \\
(0.241)\end{array}$ & $\begin{array}{l}0.269 \\
(0.252)\end{array}$ & $\begin{array}{l}0.488 \\
(0.246)\end{array}$ & $\begin{array}{c}0.266 \\
(0.253)\end{array}$ \\
\hline Net total social expenditure $(\Delta \log N S E)$ & - & $\begin{array}{l}-0.081 \\
(0.044) * * *\end{array}$ & - & - & - & - \\
\hline Public social expenditure $(\Delta \log P S E)$ & - & - & $\begin{array}{l}-0.189 \\
(0.055)^{* * *}\end{array}$ & - & $\begin{array}{l}-0.168 \\
(0.055)^{* * *}\end{array}$ & - \\
\hline Private social expenditure $(\Delta \log \operatorname{Pr} S E)$ & - & - & - & $\begin{array}{c}0.006 \\
(0.006)^{*}\end{array}$ & - & $\begin{array}{l}0.006 \\
(0.006)^{*}\end{array}$ \\
\hline Constant & 0.516 & 0.472 & 0.499 & 0.478 & 0.442 & 0.481 \\
\hline Observations & 869 & 869 & 869 & 869 & 869 & 869 \\
\hline Log likelihood & $1981-2013$ & $1981-2013$ & $1981-2013$ & $1981-2013$ & $1981-2013$ & $1981-2013$ \\
\hline Countries & 33 & 33 & 33 & 33 & 33 & 33 \\
\hline
\end{tabular}

Note: Standard errors are in parentheses. ${ }^{*}$ statistical significance level is $*-10 \%$; ${ }^{*}-5 \%$; ${ }^{* *}-1 \%$. The results of the Pooled Mean Group (PMG) procedure are calculated for both short and long-term dynamics, but the coefficients included in the table describe the long-term dynamics.

The coefficients of the general and public social expenditure growth are negative and significant, while those for the private expenditure growth are positive, which in general confirms the hypothesis on the positive impact of the increase in the share of social expenditures, financed from sources, which are formed according to the accumulative principle of financing.

Approximate coefficients for the selected indicators have been obtained using also another research method - Fixed Effect Model. It should be also noted that when using the Fixed Effect Model, all variables were obtained with expected signs, although in this method, the growth rate of the able-bodied population is a negligible factor (Table 8).

The results obtained using two evaluation methods showed a negative impact of the growth rate of social expenditure on the economic growth rate. An increase in the social expenditure growth rate by $1 \%$ in the long-term perspective will reduce the economic growth rate by $0.05-0.08 \%$. That is, if the share of total social expenditure in OECD countries' GDP grows from 21.1\% (2013 figure) to
$22.1 \%$, GDP growth will decrease by $0.38 \%$. At the same time, the increase in the share of investment in GDP by $1 \%$ leads to GDP growth by $0.2 \%$, and the increase in the number of schooling years by 1 - by $0.69 \%$.

With that, the calculation results showed a positive effect of the growth rates of private social expenditure on the economic growth compared to the state social expenditure. So, if the increase in the rate of state social expenditure by $1 \%$ leads to an economic growth reduction by $0.084-0.189 \%$ (the increase in the share of public social expenditure in the OECD's GDP from $21.1 \%$ in 2013 to $22.1 \%$ will reduce the economic growth by $0.89 \%$ ), the growth of private spending by $1 \%$ leads to an acceleration of economic growth by $0.006-0.011 \%$ (if the share of public social expenditures in OECD GDP is increased from $2.6 \%$ in 2013 to $3.6 \%$, then it will affect the GDP growth by $0.42 \%$ ).

The results on the impact of public and private social expenditures can be interpreted through differences in approaches to both the formation and use of social protection funds. In the first case (public social expenditure), the formation 
Table 8. Assessment of the social expenditure impact (public and private) on the economic growth

\begin{tabular}{|c|c|c|c|c|c|c|c|c|}
\hline \multirow{4}{*}{ Estimated coefficients } & \multicolumn{8}{|c|}{ Total population } \\
\hline & \multicolumn{4}{|c|}{ Pooled Mean Group (PMG) procedure } & \multicolumn{4}{|c|}{ Fixed Effect Model } \\
\hline & 1 & 2 & 3 & 4 & 5 & 6 & 7 & 8 \\
\hline & Baselin & Net total & Public & Private & Baselin & Net total & Public & Private \\
\hline Lagged real GDP $(\Delta \log Y-1)$ & $\begin{array}{c}-0.012 \\
(0.005)^{* *}\end{array}$ & $\begin{array}{c}-0.015 \\
(0.007)^{* *}\end{array}$ & $\begin{array}{c}-0.015 \\
(0.008)^{* *}\end{array}$ & $\begin{array}{c}-0.012 \\
(0.005)^{* *}\end{array}$ & $\begin{array}{c}-0.007 \\
0.002)^{* * *}\end{array}$ & $\begin{array}{c}-0.006 \\
(0.002)^{* * *}\end{array}$ & $\begin{array}{c}-0.006 \\
0.002)^{* * *}\end{array}$ & $\begin{array}{c}-0.006 \\
(0.002)^{* * *}\end{array}$ \\
\hline $\begin{array}{l}\text { Physical capital accumulation } \\
(\Delta \log S K)\end{array}$ & $(0.011)^{* * *}$ & $\begin{array}{c}0.038 \\
(0.009)^{* * *}\end{array}$ & $(0.010)^{* * * *}$ & $(0.011)^{* * *}$ & $\begin{array}{c}0.015 \\
(0.006)^{* *}\end{array}$ & $\begin{array}{c}0.015 \\
(0.006)^{* *}\end{array}$ & $\begin{array}{c}0.016 \\
(0.006)^{* *}\end{array}$ & $\begin{array}{c}0.015 \\
(0.006)^{* *}\end{array}$ \\
\hline $\begin{array}{l}\text { Stock of human capital } \\
(\Delta \log H)\end{array}$ & $\begin{array}{c}0.019 \\
(0.019)^{*}\end{array}$ & $\begin{array}{c}0.027 \\
(0.019)^{*}\end{array}$ & $\begin{array}{c}0.019 \\
(0.019)^{*}\end{array}$ & $\begin{array}{c}0.023 \\
(0.019)^{*}\end{array}$ & $\begin{array}{c}0.051 \\
(0.012)^{* * *}\end{array}$ & $\begin{array}{c}0.053 \\
(0.012)^{* * *}\end{array}$ & $\begin{array}{c}0.054 \\
(0.012)^{* * *}\end{array}$ & $\begin{array}{c}0.050 \\
(0.012)^{* * *}\end{array}$ \\
\hline Population growth $(\Delta \log P)$ & $\begin{array}{c}0.236 \\
(0.259)\end{array}$ & $\begin{array}{c}0.366 \\
(0.249)\end{array}$ & $\begin{array}{c}0.411 \\
(0.241)\end{array}$ & $\begin{array}{c}0.269 \\
(0.252)\end{array}$ & $\begin{array}{l}-0.166 \\
(0.189)\end{array}$ & $\begin{array}{l}-0.159 \\
(0.188)\end{array}$ & $\begin{array}{l}-0.165 \\
(0.187)\end{array}$ & $\begin{array}{l}-0.198 \\
(0.188)\end{array}$ \\
\hline $\begin{array}{l}\text { Net total social expenditure } \\
(\Delta \log N S E)\end{array}$ & - & $\begin{array}{c}-0.081 \\
(0.044)^{* * *}\end{array}$ & - & - & - & $\begin{array}{l}-0.046 \\
(0.023)^{* *}\end{array}$ & - & - \\
\hline $\begin{array}{l}\text { Public social expenditure } \\
(\Delta \log P S E)\end{array}$ & - & - & $\begin{array}{c}-0.189 \\
(0.055)^{* * *}\end{array}$ & - & - & - & $\begin{array}{c}-0.084 \\
0.024)^{* * *}\end{array}$ & - \\
\hline $\begin{array}{l}\text { Private social expenditure } \\
(\Delta \log \operatorname{Pr} S E)\end{array}$ & - & - & - & $\begin{array}{c}0.006 \\
(0.006)^{*}\end{array}$ & - & - & - & $\begin{array}{l}0.011 \\
(0.004)^{* * *}\end{array}$ \\
\hline Constant & 0.516 & 0.472 & 0.499 & 0.478 & & & & \\
\hline Observations & 869 & 869 & 869 & 869 & 902 & 902 & 902 & 902 \\
\hline Log likelihood & 1981-2013 & $1981-2013$ & $1981-2013$ & $1981-20131$ & $1981-2013$ & $1981-2013$ & $1981-2013$ & $1981-2013$ \\
\hline R-squared & - & - & - & - & 0.125105 & 0.129165 & 0.137213 & 0.132329 \\
\hline Prob & - & - & - & - & 0.000000 & 0.000000 & 0.000000 & 0.000000 \\
\hline Schwarz criterion & - & - & - & - & -4.184351 & -4.181459 & -4.190743 & -4.185098 \\
\hline Hannan-Quinn crit. & - & - & - & - & -4.306156 & -4.306556 & -4.315840 & -4.310195 \\
\hline Durbin-Watson stat & - & - & - & - & 1.335584 & 1.324878 & 1.321316 & 1.361861 \\
\hline Countries & 33 & 33 & 33 & 33 & 33 & 33 & 33 & 33 \\
\hline
\end{tabular}

Note: Standard errors are in parentheses. ${ }^{\star}$ means statistical significance level at $10 \%$; ${ }^{* *}$ at $5 \%$; ${ }^{* *}$ at $1 \%$. The results of the Pooled Mean Group (PMG) procedure are calculated both for short- and long-term dynamics, but the coefficients included in the table describe the long-term dynamics.

and use of financial resources for social protection negatively affects economic development. Funds are formed mainly at the expense of either insurance premiums in compulsory state social insurance funds or at the expense of taxes and dues to the budget system. All this creates a tax burden on business, which manifests itself both through the reduction of financial resources for investment activities in private structures and through the informal (shadow) economy formation. At the same time, the current proceeds are predominantly intended to finance current social expenditures.

In the second case (private social expenditure), the formation of financial resources though carried out at the expense of contributions, which increases the cost of business structures, but the social expenditure financing is carried out at the expense of accumulated funds. Due to this principle of financing, considerable financial resources are being drawn up, which are aimed at investing. Thus, for example, the total assets of the OECD NPF increased from 104.1\% of GDP in 2006 to $125.7 \%$ of GDP in 2016. In terms of value, the total assets of the OECD NPF increased from USD 25.34 trillion in 2006 to USD 38.14 trillion in 2016 (OECD, 2017).

The calculations performed using the Pooled Mean Group (PMG) procedure allowed to assess the impact of public and social expenditures on social policy models (Table 9).

As a result of the calculations, the following findings were obtained: with an increase in the share 
Table 9. Assessment of the social expenditure impact (public and private) on economic growth according to social policy models

\begin{tabular}{|c|c|c|c|c|c|c|}
\hline \multirow[b]{3}{*}{$\begin{array}{c}\text { Estimated } \\
\text { coefficients }\end{array}$} & \multicolumn{6}{|c|}{ Pooled Mean Group (PMG) procedure } \\
\hline & \multicolumn{6}{|c|}{ Total population } \\
\hline & $\begin{array}{c}\text { Anglo-Saxon } \\
\text { model (liberal, } \\
\text { neoliberal, } \\
\text { transatlantic) }\end{array}$ & $\begin{array}{c}\text { Continental } \\
\text { European } \\
\text { model } \\
\text { (Bismarck, } \\
\text { conservative- } \\
\text { corporate) }\end{array}$ & 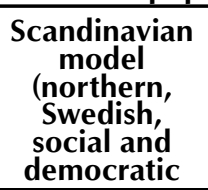 & $\begin{array}{c}\text { Mediterranean } \\
\text { model } \\
\text { (southern) }\end{array}$ & $\begin{array}{c}\text { Central- } \\
\text { Eastern } \\
\text { European } \\
\text { model }\end{array}$ & $\begin{array}{c}\text { Liberal and } \\
\text { conservative } \\
\text { model }\end{array}$ \\
\hline $\begin{array}{l}\text { Net total social } \\
\text { expenditure } \\
(\Delta \log N S E)\end{array}$ & $\begin{array}{l}-0.069 \\
(0.031)^{* *}\end{array}$ & $\begin{array}{l}-0.329 \\
(0.166)^{*}\end{array}$ & $\begin{array}{l}-0.029 \\
(0.034)^{*}\end{array}$ & $\begin{array}{l}-0.138 \\
(0.081)^{*}\end{array}$ & $\begin{array}{l}-0157 \\
(0.059)^{* *}\end{array}$ & $\begin{array}{l}-0.021 \\
(0.031)^{* * *}\end{array}$ \\
\hline $\begin{array}{l}\text { Public social } \\
\text { expenditure } \\
(\Delta \log P S E)\end{array}$ & $\begin{array}{l}-0.035 \\
(0.029)^{*}\end{array}$ & $\begin{array}{l}-0.691 \\
(0.196)^{* * *}\end{array}$ & $\begin{array}{l}-0.066 \\
(0.033)^{* *}\end{array}$ & $\begin{array}{c}-0.176 \\
(0.056)^{* * *}\end{array}$ & $\begin{array}{l}-0.183 \\
(0.089)^{* *}\end{array}$ & $\begin{array}{c}-0.073 \\
(0.049)^{* * *}\end{array}$ \\
\hline $\begin{array}{l}\text { Private social } \\
\text { expenditure } \\
(\Delta \log \operatorname{Pr} S E)\end{array}$ & $\begin{array}{c}0.029 \\
(0.018)^{*}\end{array}$ & $\begin{array}{c}0.005 \\
(0.014)^{*}\end{array}$ & $\begin{array}{c}0.023 \\
(0.015)^{*}\end{array}$ & $\begin{array}{c}0.004 \\
(0.007)^{*}\end{array}$ & $\begin{array}{c}0.001 \\
(0.005)^{*}\end{array}$ & $\begin{array}{c}0.011 \\
(0.008)^{*}\end{array}$ \\
\hline Observations & 222 & 165 & 189 & 149 & 110 & 90 \\
\hline Log likelihood & $1981-2013$ & $1981-2013$ & $1981-2013$ & $1981-2013$ & $1981-2013$ & $1981-2013$ \\
\hline Countries & 7 & 5 & 6 & 5 & 7 & 3 \\
\hline
\end{tabular}

Note: Standard errors are in parentheses. ${ }^{*}$ means statistical significance level at $10 ;^{* *}-$ at $5 \% ;{ }^{* *}-$ at $1 \%$. The Pooled Mean Group (PMG) procedure results are calculated both for short- and long-term dynamics, but the coefficients included in the table describe long-term dynamics.

of government expenditure in GDP by $1 \%$, economic growth decreases in: the Anglo-Saxon model - by $0.21 \%$; continental European by 2.44\%; Scandinavian - by $0.27 \%$; Mediterranean - by $0.72 \%$; Central-Eastern European model - by $0.93 \%$; and liberal-conservative - by $0.42 \%$. At the same time, the increase in the share of private expenditure in the country's GDP by $1 \%$ will accelerate economic growth in: the Anglo-Saxon model - by $0.65 \%$; continental European - by $0.19 \%$; Scandinavian - by $0.54 \%$; Mediterranean - by $0.27 \%$; Central-Eastern European - by $0.23 \%$; and liberal-conservative - by $0.26 \%$
When analyzing the influence of social expenditures on the economic growth according to social models, the following pattern was found: the estimated coefficient increases with the increase in the share of the corresponding type of expenditure (public or private) in the total social costs. In the Continental European model countries, the share of public expenditures for the period 1980-2013 is $93.17 \%$, the coefficient is -0.691 , while in the countries of the liberal-conservative model, it is $80.98 \%$ and -0.073 , respectively. Such results indicate that the extent of the expenditure impact also depends on the particular social model characteristics.

\section{CONCLUSION}

Modern social protection systems in OECD countries need to be reformed because of the social and economic problems facing the world community in recent decades (the economic growth slowdown, complex demographic situation accompanied by population aging, international challenges, in particular, mass migration, etc.). This period was preceded by years of social protection systems, which were accompanied by a constant cost escalation. While in the early 1950's, social expenditure in most Western countries was about 7-10\% of GDP, then during the period 1960-1990s, they grew dynamically (by about 8\% per year), which doubled the GDP growth rate. Between 1960 and 1987, they rose 2.75 times in the United Kingdom, 3.73 in the United States, 4.6 in France, 5.1 in Sweden, and 12.84 in Japan. At the same time, certain models of social policy have been formed in different countries, differing among themselves in the conditions, forms and principles of social protection system functioning. With 
that, different approaches to the development and use of financial resources in the social protection system have been developed - in some countries the share of public expenditure prevails, while in others, it is private.

Using economic and mathematical methods it was revealed that an increase in the share of social expenditure in the country's GDP negatively affects the economic growth rates. At the same time, the increase in the share of private social expenditure (funds that are formed using the accumulation principle) contributes to the economic growth, while the increase in the share of public expenditure (the formation and use of funds is mainly based on the distribution principle) negatively affects economic growth in the long run. It has been found that the level of influence of social expenditure on economic growth varies depending on the chosen social policy model. With that, it was found that the greater the share of public expenditures in the total social costs, the higher the size of the estimated coefficients.

For study, the econometric methods of the Pooled Mean Group and the Fixed Effect Model have been used, which, according to the authors calculations and the opinion of other scientists (Bassanini et al., 2001; Arjona et al., 2002), are most suitable for the analyzed data set. The calculations were carried out based on the neoclassical model of economic growth, which included, in addition to social expenditure, investment, human capital, labor, and convergence coefficient. Using data from the OECD countries for the period from 1980 to 2013 makes it possible to assume that the results obtained are sufficiently significant and objectively and actually characterize the relationship between social expenditure and economic growth.

The results obtained suggest that in the long term, OECD countries need to stabilize the share of social expenditure in GDP (and reduce it if possible) and develop private social protection systems based on the accumulation principle of funding.

According to the authors, further studies on this issue should focus on assessing the impact of a particular social policy model on achieving the main objectives of the social protection system: reducing poverty, reducing income inequality, etc. Also, to justify the most optimal combination of public and private social expenditures, it is necessary to expand the range of factors included in the proposed model of economic growth.

\section{REFERENCES}

1. Adascalitei, D. (2012). Welfare State Development in Central and Eastern Europe: A State of the Art Literature Review. Studies of Transition States and Societies, 4(2).

2. Aiginger, K. (2008). Typologies of Social Models in Europe. WIFO.

3. Alderman, H., \& Hoddinott, J. (2010). Growth-Promoting Social Safety Nets. 2020 Focus Brief on the World's Poor and Hungry People. Washington DC: International Food Policy Research Institute.

4. Alderman, H., \& Yemtsov, R. (2012). Productive Role of Safety Nets (Social Protection and Labor Discussion Paper No.1203. Background Paper for the World Bank 2012-2022. Social
Protection and Labor Strategy). Washington DC, World Bank.

5. Andersen, T. G., \& Sorensen, B. E. (1996). GMM Estimation of a Stochastic Volatility Model: A Monte Carlo Study. Journal of Business and Economic Statistics, 14, 328352. https://doi.org/10.1080/07350 015.1996 .10524660

6. Arjona, R., Ladaique, M., \& Pearson, M. (2003). Growth, Inequality and Social Protection. Canadian Public Policy, Supplement: The Linkages between Economic Growth and Inequality, 29, 119-139. https://doi. org/10.1787/121403540472

7. Aspalter, C. (2006). The east Asian welfare model. International
Journal of Social Welfare, 15(4), 290-301. https://doi.org/10.1111/ j.1468-2397.2006.00413.x

8. Baltagi, B. H. (2005). Econometric Analysis of Panel Data.

9. Barrientos, A. (2012). Social transfers and growth: What do we know? What do we need to find out? World Development, 40(1), 11-20. https://doi.org/10.1016/j. worlddev.2011.05.012

10. Barrientos, A., \& Scott, D. (2008). Social Transfers and Growth: A Review. Manchester, UK: Brooks World Poverty Institute, University of Manchester. https://doi. org/10.2139/ssrn.1538926

11. Bassanini, A., Scarpetta, S., \& Hemmings, P. (2001). Economic 
growth: the role of policies and institutions - panel data evidence from OECD countries (OECD Economics Department Working Paper, No. 283). https://doi. org/10.2139/ssrn.265091

12. Bonoli, G., George, V., \& TaylorGooby, P. (2000). European Welfare Futures: Towards a Theory of Retrenchment. Cambridge: Polity Press.

13. Cichon, M., Scholz, W., van de Meerendonk, A., Hagemejer, K., Bertranou, F., \& Plamondon, P. (2004). Financing social protection. Quantitative Methods in Social Protection. Series Geneva, International Labour Office/ International Social Security Association.

14. Commander, S. J., Davoodi, H. R., \& Lee, U. J. (1997). The Causes of Government and the Consequences for Growth and Well-Being (World Bank Policy Research Paper No. 1785).

15. Dafermos, Y., \& Papatheodorou, C. (2010). The Impact of Economic Growth and Social Protection on Inequality and Poverty: Empirical Evidence from EU Countries. Paper presented at 1st International Conference in Political Economy, September 10-12, 2010, Rethymno, Crete.

16. Damerau, T. M. (2011). Social Protection: A Necessary Condition for Economic Growth? A Guidance for Governance Decisions under Theoretical Uncertainty. Maastricht Graduate School of Governance, Maastricht University.

17. Diamond, P., \& Lodge, G. (2013). European Welfare States after the Crisis: Changing Public Attitudes. London: Policy Network.

18. Ebbinghaus, B. (2012). Comparing Welfare State Regimes: Are Typologies an Ideal or Realistic Strategy? Paper Presented at European Social Policy Analysis Network - ESPAnet Conference, Edinburgh.

19. Egger, P., Radulescu, D., \& Strecker, N. (2016). On the Spread of Social Protection Systems (UNU-WIDER Working Paper 2016/99). Helsinki: UNU-WIDER. https://doi. org/10.1007/s10797-017-9464-1
20. Esping-Andersen, G. (1990). The Three Worlds of Welfare Capitalism. Princeton: Princeton University Press.

21. Feld, L. P., \& Schneider, F. (2010). Survey on the Shadow Economy and Undeclared Earnings in OECD Countries. German Economic Review, 11/2, 109-149. https://doi/org/10.1111/j.14680475.2010.00509.x

22. Ferrera, M. (1996) The 'Southern Model' of Welfare in Social Europe. Journal of European Social Policy, 6(1), 17-37. https://doi. org/10.1177/095892879600600102

23. Furceri, D. (2010). Stabilization effects of social spending: Empirical evidence from a panel of OECD countries. The North American Journal of Economics and Finance, 21(1), 34-48

24. Furceri, D., \& Zdzienicka, A. (2012). The Effects of Social Spending on Economic Activity: Empirical Evidence from a Panel of OECD Countries. https://doi.org/10.1111/ j.1475-5890.2012.00155.x

25. Gebregziabher, F., \& Niño-Zarazúa M. (2014). Social Spending and Aggregate Welfare in Developing and Transition Economies (UNUWIDER Working Paper 2014/082) Helsinki: UNU-WIDER. https:// doi.org/10.2139/ssrn.2431213

26. Grodsky, V. S. (2015). Well-established and new ideas of the theory of economic growth and development. Regional development: an electronic scientific and practical journal, 4(8).

27. Gwartney, J. D., Lawson, R., \& Holcombe, R. G. (1998). The size and functions of government and economic growth. Joint Economic Committee.

28. Hansen, L. P. (1982). Large Sample Properties of Generalized Method of Moments Estimators. Econometrica, 50, 1029-1054. https://doi. org/10.2307/1912775

29. Hansson, P., \& Henrekson, M. (1994). A New Framework for Testing the Effect of Government Spending on Growth and Productivity. Public Choice, 8, 381-401. https://doi.org/10.1007/ BF01053239
30. Kerem, K., \& Põder, K. (2009). Possible Dilemma - Nordic Welfare State versus Anglo-American Liberal Regime: 'Estonian Social Model' in a Comparative Context. In J. Sepp, D. Frear \& W. Taylor (Eds.), The Key-factors of Business and Socio-Economic Development during the Global Crisis (pp. 89105). USA: COPE International.

31. Kostadinova, P. (2014). Social Policy Arrangements across Europe: Continuing Disparities between Social Models in the EU? L'Europe en Formation, 2014/2(n 372), 33-50. Retrieved from https://www.cairn. info/revue-l-europe-en-formation2014-2-page-33.htm

32. Levy, S. (2007). Can Social Programs Reduce Productivity and Growth? A Hypothesis for Mexico (International Policy Center Working Paper Series Number 37, January). Ann Arbor: Univesity of Michigan.

33. Li, J., \& O'Donoghue, C. (2012). A Methodological Survey of Dynamic Microsimulation Models (Working Paper Series 2012-002). Maastricht, UNU-MERIT.

34. Li, Y., Wang, X., \& Westlund, H. (2015). Physical capital, human capital, and social capital: the changing roles in China's economic growth. Growth and Change, 46(1), 133-149. https://doi.org/10.1111/ grow. 12084

35. Lucas, R. E. (1988). On the mechanics of economic development. Journal of Monetary Economics, 22(1), 3-42. https://doi. org/10.1016/0304-3932(88)90168-7

36. Magnus, Ya. R., Katyshev, P. K., \& Peresetskiy A. A. (2004). Econometrics (6th ed.). Moscow: Delo (in Russian).

37. Mankiw, G. N., Romer, D., \& Weil, D. N. (1992, May). A Contribution to the Empirics of Economic Growth. Quarterly Journal of Economics, 107, 407-437. https://doi. org/10.2307/2118477

38. Manow, P. (2010). Trajectories of Fiscal Adjustment in Bismarckian Welfare Systems. In B. Palier (Ed.), A long goodbye to Bismarck? Amsterdam: Amsterdam University Press. 
39. Miyamoto, T. (2003). Dynamics of the Japanese Welfare State in Comparative Perspective: Between Three Worlds and the Developmental State. The Japanese Journal of Social Security Policy, 2(2), 12-24.

40. Morel, N., \& Palme, J. (2013). Financing the welfare state and the politics of taxation. In B. Greve (Ed.), The Routledge handbook of the welfare state. Routledge, London.

41. Murshed, S. Mansoob, Badiuzzaman, M., \& Pulok, M. Habibullah (2017). Fiscal capacity and social protection expenditure in developing nations (WIDER Working Paper 2017/60). Helsinki: UNUWIDER. https://doi.org/10.13140/ RG.2.2.20714.52168

42. Newey, W. (1985). Generalized Method of Moments Specification Testing. Journal of Econometrics, 29, 229-256. https://doi. org/10.1016/0304-4076(85)90154-X

43. OECD (2017). Pension Markets in Focus 2017. Retrieved from http:// www.oecd.org/finance/privatepensions (application date - March 23, 2018).

44. OECD (2018). Stat. Retrieved from http://www. https://stats.oecd.org/ (application date - March 23, 2018).
45. Palier, B. (2006). The politics of reforms in Bismarckian welfare systems. Revue Française des Affaires Sociales, 1, 47-72.

46. Piachaud, D. (2011). Social Protection, Redistribution and Economic Growth. London School of Economics.

47. Püss, T., Viies, M., \& Maldre, R. (2010). EU-12 Countries in The Context of European Social Model Types. International Business \& Economics Research Journal, 9(12), 37-48.

48. Ratnikova, T. A. (2004). Analysis of panel data in the "Stata" packet. Methodical recommendations to "Economic analysis of panel data" computer practical course. Moscow: Higher School of Economics (in Russian).

49. Romer, P. M. (1986, October). Increasing Returns and Long-Run Growth. The Journal of Political Economy, 94(5), 1002-1037. https://doi. org/10.1086/261420

50. Sahn, D., \& Alderman, H. (1996). The Effect of Food Subsidies on Labor Supply in Sri Lanka. Economic Development and Cultural Change, 45(1), 125-145. https:// doi.org/10.1086/452260
51. Sinanoglu, S. (2013). The Road not Taken: A Typologyof the Welfare Regimes in the Middle East and North Africa. Student Essay, Bogazici University, Istanbul, Turkey.

52. Solow, R. (1956). A Contribution to the Theory of Economic Growth. Quarterly Journal of Economics, 70, 65-94. https://doi. org/10.2307/1884513

53. Stephen, Kidd (2016). Fiscal Space for Social Protection: Harmonization of Contributory and Non-Contributory programmes. Retrieved from http://socialprotection.org/ sites/default/files/publications_ files/harmonization $\% 20$ of $\% 20$ contributory $\% 20$ and $\% 20$ non $\% 20$ contributory\%20programmes $\% 20$ version\%20final_0.pdf

54. Swan, T. (1956). Economic Growth and Capital Accumulation. The Economic Record, 32, 334-361. https://doi. org/10.1111/j.1475-4932.1956. tb00434.x

55. Tridico, P., \& Meloni, W. (2018, February). Economic growth, welfare models and inequality in the context of globalisation. The Economic and Labour Relations Review. https://doi. org/10.1177/1035304618758941 